O. Shmatko ${ }^{1}$, Liang Dong ${ }^{1}$, A. Havrylova ${ }^{2}$, V. Aleksiyev ${ }^{2}$

${ }^{1}$ National Technical University "Kharkiv Polytechnic Institute", Kharkiv, Ukraine

${ }^{2}$ Simon Kuznets Kharkiv National University of Economics, Kharkiv, Ukraine

\title{
A NEW FRAMEWORK DESIGNED FOR KNOWLEDGE MANAGEMENT IN DISTRIBUTED SOFTWARE DEVELOPMENT
}

\begin{abstract}
The software development with distributed teams becomes a critical popular nowadays. Not only for the efficiency and effectiveness the distributed teams provide, but also the distributed teams can supply whole-day works with lower costs. Software development is a kind of knowledge-driven industry which depends on the expertise of employees. Although many scholars have long investigated knowledge management as well as distributed software development, the combination that knowledge management in distributed software development is not a enough explored topic in the past decade's years. In this paper, a review of relevant extant literature on knowledge management in distributed software development is provided. The relationship between two objects and the factors on knowledge sharing are summarized. By analysis of the characteristics and features of knowledge management, the social media-based framework of knowledge management for distributed software development is proposed.
\end{abstract}

Keywords: distributed software development; knowledge management; knowledge sharing; knowledge transfer; systematic literature review.

\section{Introduction}

Nowadays, more and more software development teams move towards distributed software development. Distributed software development is a tendency for that it extends the work day by different time zone and obtains highly specialized talent as well as more diverse labor with lower cost in a different place [1]. Software development is a kind of knowledge-oriented activity. For distributed software development, creativity is a primary factor that is used to satisfy the rapidly changed requirement. Creativity is both survivals as well as a competitive competency that improve the performance of software development team [4].

To obtain a competitive advantage, a software development team should consider the knowledge in the correct location to activate appropriate action [2]. Dutta [3] proposed that effective knowledge management is beneficial to create products with high quality and increase the innovative capacity of teams. Knowledge management $(\mathrm{KM})$ is a method that simplifies the process for knowledge creation, sharing, distributing and understanding.

Knowledge management enables knowledge creation, knowledge communication, knowledge application and disciplined actions to achieve business goals. By KM, the knowledge of critical technology is transformed from personal knowledge to team knowledge. It is conveniently for new members to study and share. For organizations, knowledge management deals with strategies, methods, processes, tools as well as technologies. In early time, the processes of knowledge management in distributed software development can be divided into four parts: searching existing knowledge, creating new knowledge, packaging knowledge and externally using knowledge.

Then the theory of knowledge management process evolves into new four processes: knowledge creation, knowledge storage and retrieve, knowledge transferring and knowledge application. As an original part, organizational knowledge creation always appears accompanying with a new component included and old component substituted. As there is adequate useful knowledge in the organization, the technology for knowledge storage and knowledge retrieval is necessary.

Organization's memory is a carrier of knowledge, which includes knowledge stored in the electronic database, articulated organizational procedure and tacit knowledge among individuals [13]. Knowledge distribution involves in three elementary units: sender, receiver and knowledge flow in the channel. The quality of knowledge distribution depends on the interpreting ability of receiver, the effectiveness of knowledge flow and the expressing ability of the sender. With the support of knowledge management, knowledge application can be achieved by embedding knowledge into organizational routines.

Organizational routine is in accordance with the distributed software development process, which contains the development of tasks, process specification and helps team member to integrate project. The knowledge management system can enhance knowledge integration by capturing, updating access to organizational directives.

\section{Extant knowledge model}

According to the characteristics of knowledge management, the literature draws an abstract concept on subject presenting three models for knowledge management: the Japanese approach [6], the resourcebased approach and the process-based approach [11]. Especially, the Japanese approach based on knowledge spiral is future-oriented.

The combination with two forms of knowledge (tacit knowledge and explicit knowledge) [5], four modes for demonstrating the management of knowledge are proposed by Nonaka [6]. Four modes in knowledge management are illustrated as Fig. 1. As Fig. 1 shows, knowledge management process includes socialization, externalization, internalization, and combination. Socialization represents tacit knowledge flow from person to person. 


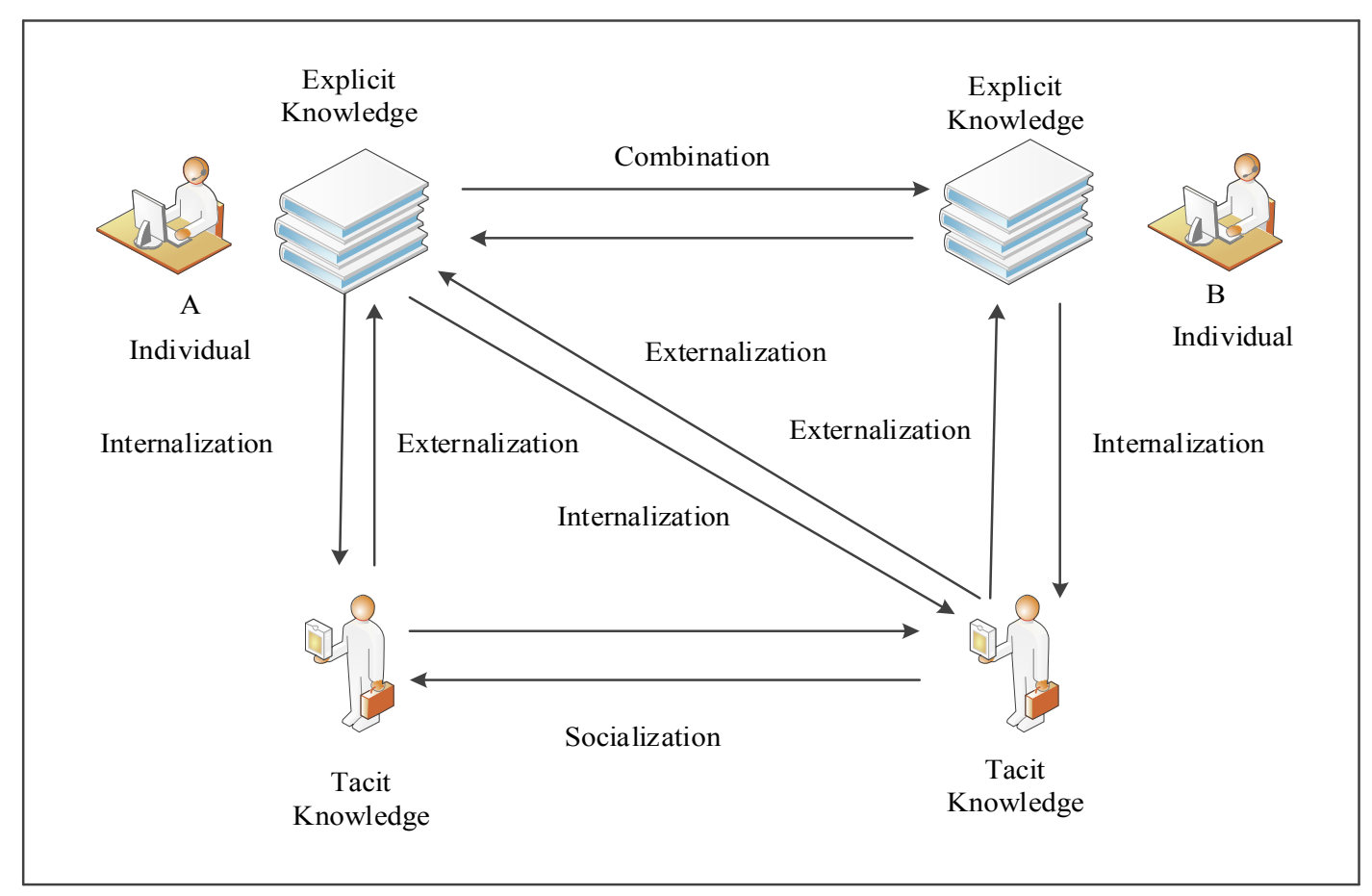

Social Knowledge

Fig. 1. Four modes for knowledge creation

Team members share their experience with others through social conversation [7]. In this process, new knowledge always appears when an individual is triggered by interaction with others. The process of combination usually just integrates and synthesizes existed knowledge without new knowledge appearance. This process, in fact, consists of two small processes: internalization and externalization. By internalization, team members learn tacit knowledge from explicit knowledge. Then new explicit knowledge is obtained by tacit knowledge using externalization. In the internalization process, team members create new tacit knowledge by reading existed explicit knowledge. And externalization has inverse meaning. Team members transfer their tacit knowledge to explicit knowledge by documentation [7].

\section{Media-based knowledge sharing}

Because creativity is rather a social process than an individual process, networks and interactions play an important role in idea creation [19]. Some literature particularly emphasizes the importance of knowledge sharing in the project $[8-11,16]$. In the process of knowledge management, the same mistakes can be avoided by knowledge sharing and the dependency on individuals is reduced [15]. Knowledge sharing provides task information to team members so that team members can collaborate for solving problems and creating new ideas [17]. Considering the method of knowledge sharing, face-to-face is regarded as one of the most effective communicative approach [14]. However, for distributed software development teams, the limitation caused by geography, time-zone, and linguistics disallows the communication in face-to-face.

Synchronous communication brings much time cost and reduces the chance of an informal meeting between co-located team members. To overcome the challenges brought by distributed software development, some scholars think highly of the importance of social media for knowledge sharing. Nearly $50 \%$ of organizations have applied social media to increase the speed of knowledge acquirement [20]. Data confirmed that the creativity of employees is positively associated with their participation in social networks. The usage of social media includes searching, reading and storing information; discussing, sharing and creating information [21]. In [22], Hinds find that the individuals are apt to share their identity when they are in socially bond. Zahedi [23] point out that in distributed software development email is the dominant communication medium which is followed by a telephone/audio conference, an instant message as well as Skype.

Social media provide a chance to make 4 operations like creation, debate, dissemination, and storage of knowledge. It gives an open knowledge distribution mechanism that expands the boundary of distributed software development and strengthens the interaction between team members. In [18], a forum named DIALOGOI is constructed which contains 4 above mentioned elementary operations for knowledge management. Besides, the forum can enhance and transform opinions of individuals, thought exchange and understanding the background of various topics.

Expert knowledge is a key fortune for software development. Many software development teams can hardly catch the expert knowledge residing in team members' mind, which is called tacit knowledge. Therefore, they cannot utilize extant knowledge resource which disturbs the creation of team members. 
However, Ryan [25] points that the more social interaction in the development team, the more tacit knowledge is shared. Cabrera [26] assured that there is a positive relationship between knowledge exchange and extrinsic rewards. On the contrary, Foss [27] have a different opinion that external monetary rewards are negatively associated with attitudes of knowledge sharing. Forum as a social instrument constructs a more rational and healthier atmosphere for knowledge sharing. It is a kind of non-monetary encouragement for distributed team members to self-motivated share their own knowledge to others.

Meanwhile, the process of the match before knowledge sharing should be considered at first. A team member cannot possess the whole knowledge from the software development process [24]. Thus, it seems that different positions have different knowledge. Thus, knowledge sharing process more likely occurs among team members at the same aspect. The knowledge management framework should provide a mechanism that team members can search others with similar education, skills, and professional aspect to share knowledge appropriately and precisely.

The process for the literature search, based on the choice of method and statistics to analyze the research on knowledge management. The match model and knowledge management framework are designed, and accordingly considered its limitation are discussed.

\section{Method and a search strategy}

Systematic Literature Review (SLR) method [28] is used to make summaries, analysis on collected published primary researches. According to the method SLR, the specified research questions should be proposed at first and then search process including search string and other criteria is indicated. After that, the standards on inclusion and exclusion are defined. Finally, data is extracted, and the conclusion is drawn.

As the background of knowledge management has been discussed above, there are several addressed questions:

1) what kind of factors that influence knowledge management in distributed software development?

2) what kind of factors that influence knowledge sharing?

For searching appropriate publications, Boolean operation "OR" and "AND" is applied. Synonymous vocabulary is considered to promise to obtain datum as more as possible. The searching string includes "software development", "distributed software development", "global software development", "knowledge management", "knowledge sharing", "knowledge exchange", "knowledge creation", "distributed team for software development", "software development in multisite" and "knowledge management in distributed software development". Among searching string with similar expression (for example "global software development" and "distributed software development") the Boolean operation "OR" is adopted while for a searching string in different expression (like "software development" and "knowledge management") the Boolean operation "AND" is applied. In order to get datum with high quality, only recently published articles with a high cited number are considered. And for every selected article, its references are also considered.

\section{Publication selection}

The inclusion criteria are: for publication date within 3 years, the cited number is no less than 10; if the publications are published for 3 to 5 years, the cited number should be larger than 30 ; if the time is more 5 years, the cited number is 50 at least. The selected papers should have a close correlation with the proposed research question. And the papers are published in English. The paper which cannot satisfy any abovementioned criterion will be excluded.

\section{Initial results}

There are so many articles from the journal, conference, transaction, but the quality and relevance to a topic in this paper are limited. In order to answer the research questions, 15 articles with high quality are selected from corresponding datasets, which are shown in Table 1.

\section{Table 1 - Selected articles for the SLR}

\begin{tabular}{|c|c|l|c|}
\hline Reference & $\begin{array}{c}\text { Publish } \\
\text { date }\end{array}$ & \multicolumn{1}{|c|}{ Resource } & $\begin{array}{c}\text { Cited } \\
\text { number }\end{array}$ \\
\hline$[1]$ & 2014 & IEEE Xplore & 34 \\
\hline$[2]$ & 2015 & $\begin{array}{l}\text { European Journal of } \\
\text { Social Sciences }\end{array}$ & 56 \\
\hline$[4]$ & 2012 & $\begin{array}{l}\text { Academy of } \\
\text { Management Journal }\end{array}$ & 389 \\
\hline$[8]$ & 2016 & $\begin{array}{l}\text { Technology Analysis } \\
\text { \& Strategic } \\
\text { Management }\end{array}$ & 12 \\
\hline$[9]$ & 2016 & Conference & 14 \\
\hline$[10]$ & 2016 & ACM & 67 \\
\hline$[14]$ & 2007 & IEEE Xplore & 67 \\
\hline$[15]$ & 2002 & Wiley & 65 \\
\hline$[17]$ & 2015 & Springer & 40 \\
\hline$[19]$ & 2013 & Taylor \& Francis & 96 \\
\hline$[21]$ & 2015 & Elsevier & 95 \\
\hline$[22]$ & 2006 & ACM & 187 \\
\hline$[23]$ & 2016 & ACM & 47 \\
\hline$[24]$ & 2003 & IEEE Xplore & 165 \\
\hline$[25]$ & 2013 & Elsevier & 94 \\
\hline$[28]$ & 2007 & ACM & 4004 \\
\hline
\end{tabular}

The factors that influence knowledge management and knowledge sharing is summarized in Table 2 .

Table 2 - The factors and corresponding frequency as well as the percentage

\begin{tabular}{|l|c|c|}
\hline \multicolumn{1}{|c|}{ Factors } & Frequency & Percentage (\%) \\
\hline $\begin{array}{l}\text { Temporal, geographic } \\
\text { and different culture }\end{array}$ & 8 & 53.33 \\
\hline Communication & 13 & 86.67 \\
\hline Social culture & 11 & 73.33 \\
\hline Networks & 11 & 73.33 \\
\hline Common interests & 9 & 60 \\
\hline The size of the project & 5 & 33.33 \\
\hline Infrastructure & 10 & 66.67 \\
\hline Physical environment & 3 & 20 \\
\hline Cost & 7 & 46.67 \\
\hline
\end{tabular}


As a result of the analysis, it can be found that the most relevant factor is "communication" (nearly $86.67 \%$ ).

However, for distributed software development, communication becomes a big challenge. The knowledge management framework should provide adequate tools for communication, such as email, instant message.

The second highest frequently referred is "Social culture" and "Networks" (73.33\%) while the social culture corresponds to the procedure "Socialization" in the SECI model [6]. A healthy social culture encourages team members communicating with each other and fostering knowledge sharing.

Meanwhile, the network provides a physical environment to construct a social culture. "Common interest" with a $60 \%$ rate is another key factor. It requires that team members have common interests which are also a prerequisite for communication and knowledge sharing. Especially, factor "Temporal, geographic and different culture" in $53.33 \%$ also plays an important role in knowledge management. The different time zone, physical location, and culture disturb knowledge management in distributed software development. Almost $46.67 \%$ articles emphasize the importance of cost. For distributed software development, the primary aim is to low labor cost. Reversely, distributed distance also increases the cost of communication.

\section{Similarity evaluation model}

Because knowledge sharing often occurs among team members on common interests, the model for evaluating the similarity between two team members is proposed. Besides, as communication and social culture, network are three main factors that influence knowledge management, a web-based forum framework is constructed.

In knowledge management, a team member does not need to connect with all the others. It only should connect with the team member which behavior similarly to it. The mathematical formulation to calculate the similarity between two team members is:

$$
K N_{\text {sim }}(X, Y)=\sum_{i} \operatorname{sim}\left(a_{X i}, a_{Y i}\right) /(|X| \cdot|Y|),
$$

where $K N_{\text {sim }}(X, Y)$ - the formulation is the similarity between team membes $X$ and $Y$;

$$
\operatorname{sim}\left(a_{X i}, a_{Y i}\right) \text { - the formulation is the similarity of }
$$

$i$-th feature;

$$
|X|,|Y| \text { - the numbers of features in } X \text { and } Y
$$

respectively.

These features can be software development language, position etc. As the numbers of features in two team members are different, the similarity needs the process of formalization, so the result is divided by $|X| \cdot|Y|$ in last. On the same time, $\operatorname{sim}\left(a_{X i}, a_{Y i}\right)$ is described as:

$$
\operatorname{sim}\left(a_{X i}, a_{Y i}\right)=\sum_{j} w_{i j} \cdot \operatorname{bina}\left(a_{X j i}, a_{Y j i}\right) / \sum_{j} w_{i j},
$$

where $w_{i j}$ is the weight of $j$-th selection in feature $i$; $\operatorname{bina}\left(a_{X j i}, a_{Y j i}\right)$ - calculates the binary distance of knowledge features between two knowledge nodes.

\section{The web-based knowledge management framework}

The structure of the knowledge management framework includes function structure and data structure. Structure of the knowledge management system indicates the form of data which is deposited in the database.

A complete knowledge management framework should satisfy the elementary requirement of distributed software development. It can edit, deposit, search and integrate knowledge. Besides, a practical system have to certainty obey the software development modes (such as Agile, Waterfall, RUP etc.). But for a knowledge management framework in modern software development mode, these functions are not enough. To enhance the competitiveness of the company, a knowledge sharing culture should be constructed within the organization.

The knowledge management system should act as a convenient and direct knowledge sharing the medium. Team members exchange their thoughts and learn new knowledge through the system. In view of characteristics of distributed software development, the communications among team members are not ideal. For that different location and time zone, the communications are often asynchronous. The system designs a synchronous mechanism that team members can contact to others by sending instant messages. This mechanism can highly reduce communication cost and save time expense.

The framework of the knowledge management system is shown on Fig. 2.

In modern conditions, software development is conducted in the direction of developing web-based systems. This is due to the global nature of the software ussng and the cloud computing technologies development . In turn, web-based systems have two distinct architectural solutions: monolithic systems and microservices.

For the first case, the knowledge and experience of the teams on interaction and system development in accordance with the object-oriented approach are relevant.

The second direction focuses more on distributed systems and their interaction via API (Application Program Interface). In any case, the work of distributed development teams is optimized at the level of the proposed framework and the corresponding development management.

From Fig. 2, the knowledge management system is composed of five parts: product development, documentation, project, roles, and forum. The forum is a kind of electronic community, which is desired to encourage knowledge sharing and transformation from tacit knowledge to explicit knowledge. Like "Quora", it provides a bulletin for team members to online edit; modify their questions. 


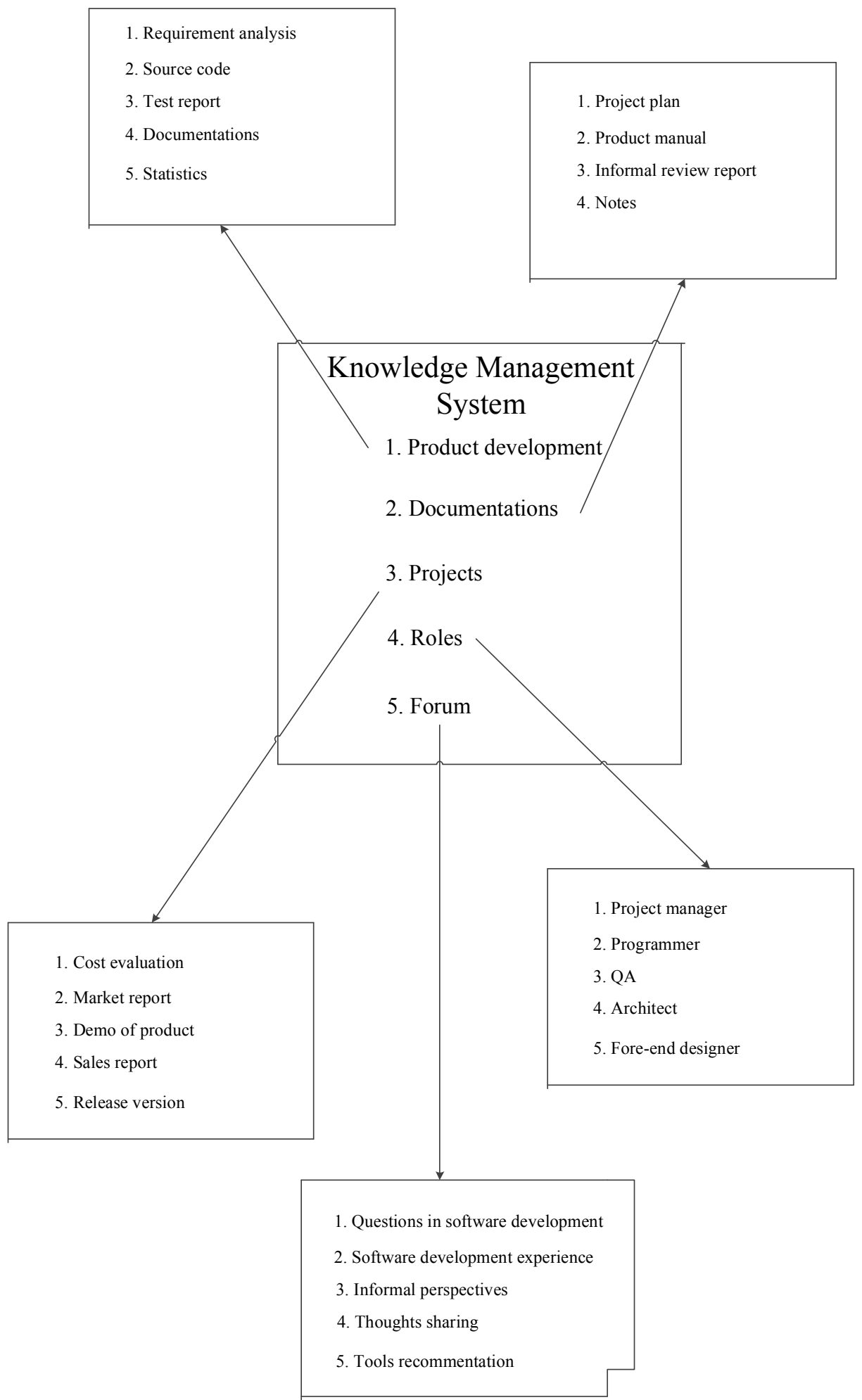

Fig. 2. The framework of the knowledge management system

It is a kind of knowledge market letting team members sharing, learning and presenting. Team members can share the software development tools that they think are effective and efficient on the forum.

The advantage of the forum is based on considering a specific problem, where the distributed development team gets a record in the knowledge base about the received direction or reception of the development, etc. In turn, for communication in today's environment in the space of distributed development teams, is a more suitable approach based on the exchange of instant or short messages, such as Skype, Slack, Telegram and then some. Such a decision should be considered rather as a management method, in turn of the thread of instant messages, which is aimed at solving a problem nature, should be transferred to the forum, which will give a long-term archive of knowledge in the relevant topic. In fact, this contributes 
to the synergy between tacit knowledge and explicit knowledge in the frame model.

\section{Limitation}

The selected articles in this paper are created within a specific period. To purse the quality of articles, only a small number of articles are selected. Thus, the research in this paper is improper.

The technologies applied in this paper exist in current time. With the development of technology, the more convenient and rational framework will be designed. Nevertheless, the results of the analysis in this paper can still cover the most popular and advanced opinions.

\section{Conclusion}

Distributed software development has become a popular paradigm for that it offers whole-time workspace, a wide labor pool with lower cost.
However, it also brings some difficulties. Knowledge is a great fortune for modern software development firms. Thus, knowledge management should be considered seriously. The contribution of this paper can be divided into two parts: theoretical and practical. Based on a systematic literature review, the paper draws the conclusion that factors "communication", "social culture" and "network" are most mentioned for knowledge sharing and management. Based on these characteristics and features, a similar evaluation model and web-based knowledge management framework are proposed, which can help to design a rational application for practice.

In further research, the proposed model and framework could be validated in the real software industry. According to the statistics from the application, the parameter of the model and the structure of the framework can be revised and improved.

\section{REFERENCES}

1. Dingsøyr, T. and Smite D. (2014), "Managing knowledge in global software development projects", IT Professional, No. 16 (1), Jan.-Feb 2014, pp. 22-29.

2. Hajir, J.A., Obeidat, B.Y., Al-dalahmeh, M.A. and Masa'deh, R. (2015), "The role of knowledge management infrastructure in enhancing innovation at mobile telecommunication companies in Jordan”, European Journal of Social Science, No. 50 (3), Dec 2015 , pp. $313-330$.

3. Dutta, B. and Madalli, P. (2004), "Trends in knowledge modeling and knowledge management: an editorial", Journal of Manufacturing Technology Management, No. 15 (5), DOI: https://doi.org/10.1108/JKM-10-2014-0442

4. Shin, S. J., Kim, T. Y., Lee J. Y. and Bian L. (2012), "Cognitive team diversity and individual team member creativity: a cross-level interaction", Acad. Manag. J., No. 55 (1), pp. 197-212.

5. Polanyi M. (1996), “The tacit dimension”, Routledge \& Kegan, pp. 204-221.

6. Nonaka I. (1994), “A dynamic theory of organizational knowledge creation”, Organization Science, No. 5(1), pp. 14 - 37.

7. Zack M. H. (1993), "Interactivity and communication mode choice in ongoing management groups", Information System, No. 4 (3), pp. 207-239.

8. Chen, X. H., Zhou, Y., Probert, D. and Su, J. (2016), "Managing knowledge sharing in distributed innovation from the perspective of developers: empirical study of open source software projects in China", Technology Analysis \& Strategic Management, No. 29 (1), pp. 1-22.

9. Kucharska, W. and Kowalczyk R. (2016), "Trust, collaborative culture and tacit knowledge sharing in project management a relationship model", Proceedings of the 13th International Conference on Intellectual Capital, Knowledge Management \& Organizational Learning: ICICKM, pp. 159-166.

10. Lee, J.C., Shiue, Y.C. and Chen, C.Y. (2016), "Examining the impacts of organizational culture and top management support of knowledge sharing on the success of software process improvement", Computers in Human Behavior, No. 54, pp. 462474, DOI: https://doi.org/10.1016/j.chb.2015.08.030

11. Koriat, N. and Gelbard, R. (2014), "Knowledge sharing motivation among IT personnel: Integrated model and implications of employment contracts", International Journal of Information Management, No. 34 (5), pp. 577-591, DOI: https://doi.org/10.1016/j.ijinfomgt.2014.04.009

12. Janasz, W. and Janasz, K. (2018), "Knowledge management in a modern organization", Studies and Research of the FEM of the $S U$, No. 52 (2), pp. 25-39.

13. Walsh, J.P. and Ungson. G.R. (1991), “Organizational memory”, Academy of Management Review, No. 16 (1), pp. $57-91$.

14. Crowston, K., Howinson, J. and Masango C. (2007), "The role of face-to-face meetings in technology-supported selforganizing distributed teams" IEEE Trans. Prof. Commun., No. 50 (3), pp. 185-203.

15. Meehan, B. and Richardson I. (2002), "Identification of software process knowledge management", Software Process: Improvement and Practice, No.7(2), pp. 47-55.

16. Khan, S.U., Niazi, M. and Ahmad, R. (2009), "Critical success factors for offshore software development outsourcing vendors: a systematic literature review", Fourth IEEE International Conference in Global Software Engineering, ICGSE, pp. 207-216, doi: http://doi.org/10.1109/ICGSE.2009.28

17. Santos, V., Goldman, A. and C.R. de Souza (2014), "Fostering effective inter-team knowledge sharing in Agile software development", Empirical Software Engineering, pp. 1-46.

18. Chalkiti, K. and Sigala M. (2008), "Information sharing and knowledge creation in online forums: the case of the Greek online forum DIALOGOI”, Curr. Issues Tour., No. 11 (5), Dec 2008, pp. 381-406.

19. Hemsley, J. and Mason, R. (2012), "The nature of knowledge in the social media age: implications for knowledge management models", 45th Hawaii International Conference on System Sciences (HICSS 2012), IEEE Computer Society, DOI: http://doi.org/10.1109/HICSS.2012.580 
20. Bughin, J., Chui, M. and Manyika, J. (2012), "Capturing business value with social technologies", McKinsey on business technologies, No. 28, pp. 72-80.

21. Sigala, M. and Chalkiti, K. (2015), "Knowledge management, social media and employee creativity”, International Journal of Hospitality Management, No. 45, pp. 44-58.

22. Hinds, P. and McGrath, C. (2006), "Structures that work: social structure, work structure and coordination ease in geographically distributed teams", Proceedings of the 2006 ACM Conference on Computer Supported Cooperative Work, CSCW 2006, Banff, Alberta, Canada, November 4-8, pp. 343-352, DOI: http://doi.org/10.1145/1180875.1180928

23. Zahedia, M., Shahin, M. and Babarb, M.A. (2016), "A systematic review of knowledge sharing challenges and practices in global software development", International Journal of Information Management, No. 36 (6), pp. 995-1019, DOI: https://doi.org/10.1016/j.ijinfomgt.2016.06.007

24. Chau, T., Maurer, F. and Melnik, G. (2003), "Knowledge sharing: agile methods vs. Tayloristic methods", Proceedings of the IEEE International Workshops on Enabling Technologies: Infrastructure for Collaborative Enterprises, IEEE Computer Society, DOI: http://doi.org/10.1109/ENABL.2003.1231427

25. Ryan, S. and Connorb, R.V.O. (2013), ”Acquiring and sharing tacit knowledge in software development teams: An empirical study", Information and Software Technology, No. 55 (9), pp. 1614-1624.

26. Cabrera, A., Collins, W.C. and Salgado, J.F. (2006), "Determinants of individual engagement in knowledge sharing", The International Journal of Human Resource Management, No. 17(2), pp. 245-264.

27. Foss, N. J., Minbaeva, D. B., Pedersen, T. and Reinholt, M. (2009), "Encouraging knowledge sharing among employees: How job design matters", Human Resource Management, No. 48, pp. 871-893.

28. Kitchenham, B. and Charters, C. (2007), Guidelines for performing systematic literarature reviews in software engineering, Keele University and Durham University Joint Report.

29. Verner, J. M., Brereton, O. P., Kitchenham, B. A., Turner, M. and Niazi, M. (2014), "Risks and risk mitigation in global software development: A tertiary study", Information and Software Technology, No. 56 (1), pp. 54-78.

Received (Надійшла) 02.01.2019

Accepted for publication (Прийнята до друку) 11.02.2019

\section{Новий фреймворк для управління знаннями у ході розробки розподіленого програмного забезпечення \\ О. В. Шматко, Ліанг Донг, А. А. Гаврилова, В. О. Алексієв}

Розробка програмного забезпечення з розподіленими командами стає критично популярною в наші дні. Не тільки для забезпечення ефективності та результативності розподілених команд, але й безпосередньо для розподілених команд, можна забезпечити цілодобові роботи з меншими витратами. Розробка програмного забезпечення є своєрідною галуззю, керованою знаннями, яка залежить від досвіду співробітників. Хоча багато дослідників вже досліджували управління знаннями, а також розробку розподіленого програмного забезпечення, комбінація того, що управління знаннями в розподіленій розробці програмного забезпечення не $\epsilon$ достатньо вивченою темою в останні десятиліття. У роботі наведено огляд відповідних літературних джерел 3 управління знаннями в розробці розподіленого програмного забезпечення. Узагальнено взаємозв'язок між двома об'єктами та факторами обміну знаннями. На основі аналізу характеристик та особливостей управління знаннями, пропонується соціальна медіа-основа управління знаннями для розробки розподіленого програмного забезпечення. Пропонується модель оцінки і мережева структура управління знаннями, яка може допомогти в розробці раціонального застосування для практики. У майбутніх дослідженнях запропонована модель оцінки і структура управління знаннями можуть бути перевірені в реальній індустрії програмного забезпечення.

Ключов і слова: розробка програмного забезпечення; управління знаннями; обмін знаннями; передача знань; системний огляд літератури.

\section{Новый фреймворк для управления знаниями при разработке распределенного программного обеспечения}

А. В. Шматко., Лианг Донг, А. А. Гаврилова, В. О. Алексиев

Разработка программного обеспечения с распределенными командами становится критически популярной в наше время. Распределенные группы разработчиков обеспечивают не только эффективность и результативность проекта, но и для самих распределенных разработчиков можно обеспечить возможность выполнения работ в течение всего дня с меньшими затратами. Разработка программного обеспечения - это отрасль, основанная на знаниях, которая зависит от опыта сотрудников. Хотя многие ученые давно изучали вопросы управления знаниями, а также разработки распределенного программного обеспечения, можно утверждать, что сочетание того, что управление знаниями в разработке распределенного программного обеспеченияб не является достаточно изученной темой в последние десятилетия. В этой статье представлен системный обзор современной литературы по управлению знаниями в области разработки распределенного программного обеспечения. Связь между двумя объектами и факторами обмена знаниями суммируется. На основе анализа характеристик и особенностей управления знаниями предложен фреймворк управления знаниями для разработки распределенного программного обеспечения, который фактически основан на структуре социальных сетей. Предлагается модель оценки и сетевая структура управления знаниями, которая может помочь в разработке рационального приложения для практики. В последующих исследованиях предлагаемая модель оценки и структура управления знаниями могут быть проверены в реальной индустрии программного обеспечения.

Ключевые слова: разработка распределенного программного обеспечения; управление знаниями; обмен знаниями; передача знаний; системный обзор литературы. 